\title{
The European Union in Global Environmental Governance: Leadership in the Making?
}

\author{
John Vogler \& Hannes R. Stephan
}

\section{Introduction}

At the heart of European policy for sustainable development and global environmental governance (GEG) lies a vision quite different from that traditionally pursued by sovereign nation-states. Appealing to multilateralism and sustainability, the vision has been selfconsciously promoted as part of the emergent identity of the Union. ${ }^{1}$ The European Union pursues an ideal of collective action and actively advances its own model of regional integration. While powerful players like the United States (see Chasek, this volume) or emerging giants like China are opposed to many aspects of international regulation, the EU generally sees its own vision as being in tune with the ethos of the United Nations system itself, despite the fact that it labours under a number of disadvantages in New York, not the least of which is the inferior status of the European Community in an organisation exclusively composed of sovereign states.

Outsiders may well be sceptical, for the Union is no stranger to an aggressive pursuit of trade, agricultural or fisheries interests. Yet there is no necessary contradiction between the promotion of European values, the pursuit of interests and the strong support for a more ambitious agenda of global regulation.

In 2003, a communication from the European Commission reaffirmed Europe's commitment to a multilateral system governed through the United Nations and simultaneously highlighted ways of enhancing the EU's influence. With an implicit attempt to establish a contrasting identity to that of the United States, the EU and the UN were portrayed as holding the fate of the world in their hands:

"In the years ahead, therefore, Europe's attachment to multilateralism - and to the United Nations, as the pivot of the multilateral system - will help determine whether, and how, the institutional architecture established in the years after World War II can continue to serve as the bedrock of the international system.

\footnotetext{
${ }^{1}$ Reference to the debates on European identity and the extent to which it may merely be the reciprocal of military weakness, Kagan (2003), Rifkin,(2004) Bretherton and Vogler (2006) Ch.2.
} 
The alternative would be devastating - not only in its implications for international peace and security, but also for the wider multilateral agenda, ranging from the follow-up to recent international conferences to the development of a rule-based international trading system" (European Commission 2003: 3).

The institutional architecture would also include the setting up of the International Criminal Court and the development of the European Security and Defence Policy as a 'crisis management' capability at the service of the UN, but the focus of this article is the question of global environmental governance (GEG). Although this has been variously defined - and can be drawn extremely broadly - it is normally seen by the policy community to involve efforts to reform and reintegrate those activities and organisations bearing upon questions of environmental degradation and sustainable development, that come under the very broad umbrella of the United Nations. Thus we might include the various environmental conventions and their autonomous Conferences of the parties, the WTO, the IMF and IBRD, and numerous other development-related organisations. At the heart of the shifting discussion of sustainable development has been the Rio process, initiated by UNCED in 1992 and followed up by the meetings of its creation, the Commission for Sustainable Development (CSD). Organisationally the key body, set up by the predecessor to UNCED - the Stockholm Conference of 1972 - has been the United Nations Environment Programme (UNEP). As a programme, and hence lacking the independence of a specialised agency, UNEP has performed a 'catalytic and co-ordinating' role across a wide range of international environmental activities. The formal debate upon global governance has often converged upon its role and status as well as the linked issue of the creation of an overarching World Environment Organisation (WEO).

In all major global environmental fora, the EU has been one of the few actors to consistently argue in favour of institutional reforms and the speedy and accountable implementation of existing commitments. At times, it has even suggested equipping international institutions with legal powers of compliance monitoring (see ENB 2002: 4) - a proposition that has echoes of the internal role of the European Commission, which regularly holds national governments to account. However, there remains a "disturbing mismatch between aspirations and demands of the EU as an international actor and its relatively limited ability to deliver" (Chaban et al. 2006: 246). This involves the intractability of the subject 
matter as well as the internal and institutional problems associated with an actor comprised of 27 sovereign states.

The core arenas of global governance have all built their sometimes fragile legitimacy on a forthright commitment to development. The concept of sustainable development which despite its many ambivalent definitions - has provided the theoretical bridge connecting the environment with economy and society has proved a congenial one for the EU with its welldeveloped external aid and environmental policies. Environmental matters received no mention in the Treaty of Rome, but since the 1970s an impressive array of internal legislation has been developed to cope with the environmental effects of the success of economic integration in Europe. At the same time the Union remains, alongside the United States, a dominant player in the politics of international trade and agriculture as well as possessing a very substantial distant water fishing fleet operating under the Common Fisheries Policy. When the aid programmes of the European Community and the Member States are taken together, the Union constitutes the largest development donor on earth with a special responsibility for the 77 African Caribbean and Pacific countries. Sustainable development is now an objective of the Union (TEU Art.2) and environmental protection requirements are to be integrated into the definition and implementation of European Community's other policies and activities (TEC Art.6) ${ }^{1}$.

For now, the priorities of sustainable development remain "far from being at the centre of decision-making in the multilateral system" (Swedish EU Discussion Paper 2001: 2) and, arguably, the prevalent interpretation of sustainable development is substantially tilted towards conventional economic aspects, in particular poverty eradication and economic growth (Von Frantzius 2004). This situation has been mirrored by some of the internal difficulties and contradictions experienced by the Union and must bear upon its external legitimacy as a leader. There is a record of incoherence between environmental and trade and agricultural policies and although the Union has at least placed environmental considerations on the WTO agenda they have hardly been at the forefront of the objectives of DG Trade and DG Agriculture. In essence, the shifting global agenda has meant that environmental issues have less and less been the subject of separate, sectoral discussions and have instead begun to be integrated with other aspects of global governance, particularly with the global movement

\footnotetext{
${ }^{1}$ The TEU, Treaty on European Union was agreed at Maastricht in 1992, while the incorporation of sustainable development as a Community objective was achieved by the revision of the TEC, treaty establishing the European Community at Amsterdam in 1997.
} 
for development. ${ }^{1}$ As this article will show, the European reaction to this trend has essentially comprised two strategic responses: the EU has, on the one hand, wholeheartedly embraced the ideal of sustainable development and sought to promote it vigorously. At the same time, it has explored ways of strengthening the more focused sector of international environmental governance (IEG) to preserve an autonomous voice for the environment. Though these responses may at first glance appear contradictory, they are better described as complementary. Moreover, the results obtained so far are indicative of the moderate yet measurable impact of European positions in world politics. An analysis of the EU role and positions in the Rio process, at the CSD, and on the question of UNEP reform constitutes the main content of this article, but they must be prefaced by a consideration of the frequent but problematic assumption that the Union is an actor comparable, say, to the United States.

\section{The EU as an actor in global environmental governance}

The extent to which the EU may be regarded as an international actor in its own right, comprised as it is of the European Community and 27 Member States, continues to pose problems. ${ }^{2}$ Although it has developed extensive rights of participation in the negotiation of multilateral environmental agreements (MEAs) it has encountered particular difficulties with recognition at the UN General Assembly, within UNEP, at the 'Rio plus' conferences and within the CSD. Alongside the complex internal structures of EU policy-making, the different ways in which the Union represents itself externally prompt questions about 'who speaks for the Union', the extent to which the Union has developed a coherent line on the reform of international environmental governance and the degree to which the EU is comparable to the other actors considered in this volume.

For the Member States, the great majority of environmental legislation now originates in the form of directives of the European Community. The latter has developed policy competencies, replacing those of the Member States, for areas as significant as atmospheric pollution, water quality, marine conservation and waste management. These alongside the

\footnotetext{
${ }^{1}$ This again reflects internal problems with attempts to introduce sustainability requirements into the Union's many activities through the Cardiff Process and more recently the Sustainable Development Strategy.

${ }^{2}$ Since 1993 commentators have usually referred to the European Union - encompassing both the European Community (Pillar I of the structure agreed at Maastricht in 1992) and the Member States. However, in discussing the external role of the Union it is sometimes necessary to make the legal distinction between the Community which has its own competencies, is represented by the Commission and has international legal personality and the EU as a whole. At the UN, the distinction between the Community, which only has observer status, and the Member States who attempt to co-ordinate their actions as members of the EU, is particularly important.
} 
environmental and conservation aspects of the common policies for commerce, agriculture and fisheries mean that the Community has a substantial policy responsibility for the content of most of the forty chapters of Agenda 21.

Deriving in part from its acquisition of internal legislative powers, the European Community has been able to extend its activities to the negotiation of multilateral environmental agreements. ${ }^{1}$ It has played a leading role in the 1989 Basel Convention on hazardous waste, in the 1999 and 2001 conventions on prior informed consent procedures for hazardous chemicals (PIC) and persistent organic pollutants (POPs), and in the negotiation of the 2000 Cartagena Protocol on biosafety. In all, it is now a signatory, alongside the Member States, to in excess of 60 MEAs. ${ }^{2}$ The negotiating histories of recent conventions indicate that the EU has seized the opportunity provided by US abandonment of its previous undisputed role as a leader in international environmental policy. In doing so it has often provided a fulcrum around which the competing positions of the US and its allies and the G77 have revolved. Most striking, especially in its own estimation, but also in that of outsiders, has been the EU's leadership on the climate change issue. Having initially resisted the flexibility mechanisms of the Kyoto Protocol, it became their champion. There can be little doubt that the long-delayed elaboration and ratification of the Protocol stands as an achievement of the Union. It is, then, a very substantial, even dominant, player in international environmental politics.

To characterise the Union in such terms is to make assumptions about its status as an actor. That it constitutes a single entity distinguishable from its component 27 Member States, capable of volition and recognised by outsiders . In this special issue, a similar assumption is made about the G77, but the EU is as different from the latter as it is from the state actors that also figure ( Vogler 1999, Bretherton \& Vogler, 2006). For the international lawyers it is sui generis, not really comparable with any other entity in the international system. To use the template of the Westphalian state to measure the European Union would be to set up a standard that is in many ways irrelevant, for - despite the fears of eurosceptics -

\footnotetext{
${ }^{1}$ The Community was granted the right to take over the making of external policy from the Member States in specified areas by the TEC (see Arts. 133, 300). Elsewhere, and in the case of most environmental policy, it automatically acquired external competence when internal competence was granted. This was established by the European Court of Justice in ECJ 22/70, the European Road Transport Agreement case.

${ }^{2}$ For further details on the extent and modes of EU participation see Vogler (2003). Of the 79 agreements listed in the 2003-4 Yearbook of International Cooperation on Environment and Development, the Community was a signatory of 39 in its own right with the Member States representing the Union in a number of others such as CITES, the ocean dumping conventions and MARPOL.
} 
the EU is not in a position to become a European federation or to usurp the core sovereignty of its Member States. Neither may we portray it as an over-developed international organisation (as opposed to a deficient state). Yet it is clearly recognised as a significant and, on occasion, powerful actor by those who encounter it. Its policy competencies and legal personality, its power to bind its members, to spend large amounts of money, to exert leverage and to develop complex policy, put it in a very different class to an alliance of states.

The simple assertion that the EU 'acts' may, in practice, mean a number of things. In terms of procedure and responsibilities, the distribution of competence is highly significant and can explain some of the anomalies observed at international negotiations where different people may represent the Union at different times. Competence is the EU term for powers and there are some policy areas where, either through treaty provisions or through internal rulemaking, exclusive competence has passed from the Member States to the EC. The classic example is provided by the Common Commercial Policy (Art.133) where only the Community has the right to set tariffs and engage in trade negotiations. This in effect means that the Commission will represent the whole EU and the Member State representatives will remain silent, saving their objections and arguments for private meetings (in the case of trade this will mean the Article 133 Committee). Under exclusive competence normal Community decision-making procedures will apply. The Commission possesses an exclusive right of initiative but the Member State representatives in the Council will agree legislation and negotiating mandates usually by qualified majority vote. Under co-decision procedures the European Parliament will also have to agree legislation. As mentioned above, the Community has acquired exclusive competence for a number of significant aspects of environmental policy and there is little doubt that, when operating externally under exclusive competence, the EU appears at its most impressive as a single purposive actor, led by the Commission. In terms of environmental policy, broadly conceived, exclusive competence under the Common Fisheries Policy has meant that the Commission represented the Union at the negotiation of the 1995 UN agreement on Fish Stocks and at various international fisheries commissions.

But there are also many areas of policy, involving defence, taxation and energy for example, where exclusive competence has been jealously retained by the Member States. The clearest example is provided by the Common Foreign and Security Policy where decisionmaking procedures remain intergovernmental, an effective national veto is retained, and 
where the Commission is merely 'associated'. The practice under exclusive Member State competence is for the 'President in office' to represent the Union. With the failure to adopt the reforms contained within the Constitutional Treaty, the Presidency continues to rotate between the Member States on a six-monthly basis. The Presidency may be assisted by the 'troika' which now adds a representative of the state which will hold the succeeding presidency and a representative of the Commission.

For most environmental policy neither form of competence is fully applicable. Instead, competence is said to be 'shared' or concurrent and agreements are described as 'mixed'. The precise mix will vary and there are some areas of policy in which the Community has very extensive competence and where the Commission essentially dominates external policy. The Basel negotiations on hazardous waste and PIC and POPs provide examples. One aspect of this is legal and the often relates to the precise treaty article under which action is being taken (Arts.133 or 175, for example) but there is also the practical question of technical capability whereby the Commission may take a leading role because it has the necessary expertise or ability to develop a European approach. Climate Change negotiations, for example, are led by the Presidency but the Commission is always included and plays a significant part. Furthermore, certain Member States have tended to specialise on certain issues and are allowed to take a leading role. The Commission participated in international environmental negotiations concerning the Rhine and Mediterranean during the 1970s, but a critical breakthrough occurred in the talks to establish the 1979 Long Range Transboundary Air Pollution Convention (LRTAP). Here the concept of an REIO (Regional Economic Integration Organisation) was established, which allows the Community to participate and sign agreements alongside the Member States. In marked contrast to the situation in other UN fora, an REIO clause is now a standard feature of modern environmental conventions (for example the biodiversity and climate conventions). At a conference or meeting of the parties to one of these conventions up to $28 \mathrm{EU}$ delegations may be present, all the Member States and the Commission. Either the Commission or the Presidency may speak for all, depending upon the precise distribution of competencies for the issues under discussion, and it is possible for the Commission to cast the votes of all the Member States.

The UN remains an organisation of sovereign states and its bodies generally do not have an REIO clause. In fact, the Community is only a full member of the Food and Agriculture Organisation (FAO) and the World Trade Organisation (WTO). It was 
granted observer status by a General Assembly Resolution (29 GA Res. 3208) of 1974. Led by the President in Office, EU Member States increasingly co-ordinate their national approaches at the UN and provide the largest part of the organisation's regular budget while the Commission has delegations accredited to most UN bodies including UNEP with its headquarters in Nairobi. ${ }^{1}$ The 2004 enlargement of the Union had some novel implications in relation to the UN's regional group structure. The pre-2004 Member States are members of the Western Europe and Others Group (WEOG) where they were joined by Malta. Eight other accession states were in the East European Group, while Cyprus remains in the Asian Group. ${ }^{2}$ As will be observed below, the Community continues to have limited status and attempts to extend it have been resisted - sometimes by the Member States themselves, by the Eastern bloc during the Cold War, and latterly by the United States.

\section{The Rio Process}

The United Nations Conference on Environment and Development (UNCED) at Rio in 1992 was the first global showcase for the Union's emerging actorness. Whereas its predecessor, the UNCHE at Stockholm in1972, was influenced by the rudiments of European Community environmental policy, UNCED witnessed the emergence of the Community as a 'full participant' for the first time (Mensah 1996: 32) Despite the extensive degree of Community competence for the issues under discussion, the Commission had to negotiate hard for expanded recognition in advance of the 1992 Rio Earth Summit to acquire speaking rights equivalent to those of state participants. Its achievement was memorialised in a footnote to Agenda 21 which stated that:

When the term governments is used, it will be deemed to include the European Economic Community within its areas of competence.

\footnotetext{
${ }^{1}$ In 2003 contributions were distributed as follows: EU15 36.8\%, US 22\%, Japan 19.5\%, Accession $100.9 \%$, Rest of the world 20.7\%: Commission 2003, The enlarging European Union at the United Nations: Making multilateralism matter, Luxembourg: Office for Official Publications:6.

${ }^{2}$ UK Foreign and Commonwealth Office, Major UN Groups and Major Groupings Relating to the UN System April 2006, www.fco.gov.uk/files/kfile/unmajorgroupsandgroupingsApril2006.pdf. Group membership is important because they form the constituencies from which states are elected to serve on various UN bodies including ECOSOC, CSD and UNEP. Also selected on a group basis are the bureaux which have a continuing administrative role when conferences or commissions are not in session.
} 
The other participants insisted that this should not create any form of legal precedent and have since made the status of the EC a matter of bargaining and persuasion in major UN fora. ${ }^{1}$ It is worth remembering that UNCED was, at the time, the largest diplomatic gathering ever held and that there were inevitably underlying issues of status and recognition. Thus for Commission officials it was important that its president Jacques Delors was afforded equal treatment to other heads of government - including, of course, those of the Member States. ${ }^{2}$

The Commission played a very active role at the UNCED PrepComs, inserting text into Agenda 21 but without insisting on the inclusion of trade, an issue area in which it would have had substantial influence on the basis of its competencies and the size of the Single Market. The failure to forge a coherent link between its environmental objectives and trade ${ }^{3}$ and live up to its purported 'green' leadership role represents one of the enduring problems, or perhaps lost opportunities, of the Union. On another flank, the Member States (but not at this stage the Commission) had been negotiating what was to become the UNFCCC in the Intergovernmental Negotiating Committee. Late in the day, prior to UNCED, a concession by the British Presidency ensured that the US would sign the Convention, but only at the price of removing binding commitments to greenhouse gas emissions reductions. The then EC Commissioner for Environment, Ripa de Meana, refused to attend UNCED after the failure to agree on a convention on forests and the concession on greenhouse gas emissions, opining that: 'We are not only not saving the earth; we are not even saving our own consciences' .

Much of the business of the conference turned into a dispute over the aid commitments to the South that would be the basis upon which it could accept the environmental requirements of the North, particularly the continuing failure to live up to the long established target of $0.7 \%$ of GDP. On the latter the EC Member States were divided with France, the Netherlands and Denmark in favour and the UK opposed. Najam (2003: 369) is quite justified in writing that the Rio compact on sustainable development - the new

\footnotetext{
${ }^{1}$ Although the same formula was used for EC participation in subsequent UN conferences on Habitat, Health and Environment and Food Summit of 1996, it took three weeks of preparatory discussion to insert it into the documentation of the UN General Assembly Special Session which reviewed UNCEFD in June 1997 (Vogler, 1999:34).

${ }^{2}$ Delors did attend but was prevented from speaking at the UNCED final Plenary. As the leaders departed he, perhaps symbolically, found it necessary to hitch a ride on French President Mitterand's Concorde. At the 1997 meeting of the General Assembly Jacques Santer was afforded equivalent status.

${ }^{3}$ In this instance the problem was one of coherence within the Commission where the trade DG tended to overrule environment on the grounds that such matters should be dealt with under the GATT Uruguay Round which should not be complicated by the proceedings at UNCED (Interview Commission, 2006).

${ }^{4}$ Carlo Ripa di Meana 'Why I will stay away from the Earth Summit' Guardian, 30 may 1992. The principal reason appears to have been the failure of the Member States to agree on a proposal for carbon taxation.
} 
understanding on environment and development between North and South - "was always understood to be an expression of desire rather than reality". It surely was the strong desire of some within the EU, but the beginning economic downturn and internal resistance to the guiding norm of sustainable development undermined the Union's commitment - not only in financial terms.

Despite the difficulties encountered by the Europeans in this first appearance on the stage of global environmental governance, the overall outcome was a success - not so much for sustainable development but for the reputation of the EC. This was relative to the performance of the United States for whom the Rio proceedings were widely regarded as a diplomatic disaster. It is worthwhile to quote the views of a sceptical UK participant here, who compared the very different performances of the USA and the EC where the Member States:

"...many of which had problems similar to those identified by the Americans on such central issues as increased aid for the developing world, the deficiencies of the biodiversity convention, and high-cost action to tackle climate change, nevertheless managed to emerge from the process with their bridges to the rest of the world reinforced rather than undermined and their influence and standing enhanced rather than eroded" (Brenton, 1994: 234-5).

His explanation is interesting for it turns upon the relative insularity of the United States for whom policy has a domestic focus, by contrast:

The EC nations, by virtue of their size and proximity, are by now well adjusted and attuned to doing environmental business by international negotiation. They have learned to be attentive to international currents of opinion and to be ready to look for compromises to get an agreed result (ibid.:235).

Five years after Rio, states assembled once again at the Special Session of the United Nations General Assembly in June 1997 (UNCED+5), but due to general distrust and lack of action on Agenda 21 and the North's financial commitment, the session turned into an often acrimonious, aptly termed "do-nothing event" (Agarwal et al. 2001: 198). The EU reaffirmed its commitment to sustainable development and presented some new initiatives on water, 
energy, eco-efficiency and climate change. And, arguably again by default, it thus bolstered its status as the leader in international environmental affairs (Jordan and Voisey 1998: 97). Its proposals, however, did not meet with widespread support. The Dutch Presidency understood that G77 and China would not agree to any new compromises unless the Union showed some action on its Rio pledges, yet France and Germany scuppered the intended rethink on ODA (ibid: 94). In sum, not least due to the USA's palpable disinterest in environmental governance and this summit in particular, the EU claimed leadership once more, but it was at best commanding a ship at anchor.

\section{World Summit on Sustainable Development: holding ground}

"Compared to WSSD, UNCED was the soul of generosity", mused Tom Bigg (2003) only one year after states had convened at Johannesburg once more to review progress towards sustainable development. With the benefit of hindsight, this may not even be an exaggeration, although the European Union worked hard to avoid another stalled summit like in $1997 .{ }^{1}$ Even a new mobilising idea had been found: taking up a term coined by the South African Environment Minister Moosa, the EU proposed to work towards a 'global deal' at the United Nations Economic Commission for Europe (UNECE) preparatory meeting for the WSSD in September 2001 (Bigg 2003). The problem with it was its timing, above all. The Danish nonpaper (2001) outlining its proposed elements was produced a mere ten months before the summit itself. In principle, the 'global deal' should have been an attractive package for developing countries, offering better access to Northern markets and increased ODA, and demanding an explicit commitment to the Rio Declaration coupled with implementation in return. This was similar to the original 'Rio compact' itself and it was hoped to give Johannesburg a central, overarching achievement. Nonetheless, for reasons discussed below the 'global deal' generated little enthusiasm from key negotiating parties.

As the WSSD drew near, the 'global deal' was quietly being abandoned. The General Affairs Council Conclusions of 17 June 2002 recalled that the "EU remains open to discuss proposals made by partners or which could emerge from the international debate until Johannesburg." Furthermore, in February 2002, Commissioner Wallström mused that "the terminology is much less important than the actions we sign up to" and declared that - in

\footnotetext{
${ }^{1}$ Its preparation for the summit was meticulous, though not without fault. A stream of different Council conclusions, Commission communications and overarching pronouncements from the European Council accompanied the countdown to Johannesburg.
} 
order to avoid the expected lowest-common-denominator results - the EU would search for "coalitions of willing people" through a form of flexible geometry (Wallström 2002a). ${ }^{1}$

In essence, in 2002, DG Environment fought battles and searched for coalitions on two fronts at the same time. Internally, Commissioner Wallström struggled to create a good working relationship with Development Commissioner Nielsen with whom she shared the position of 'chef de file'. Besides the apparent "lack of chemistry" between them (Lightfoot and Burchell 2005: 82), the development sector was located in the strategically favourable median position between the DG Environment and DG Trade, the latter effectively promoting a neo-liberal agenda of poverty reduction through trade liberalisation (see ECOFIN Council 2002). ${ }^{2}$ Such internal diversity of aims was a major barrier in the negotiations.

It hardly helped the Union's internal cohesion that different member states had put forward rather diverging visions of the aims at Johannesburg and the possible content of 'global deal'. Surveying the discussion papers produced in the run-up to the conference, one is struck by the different emphases chosen by Sweden and the U.K. The former called for a reinvigorated commitment to sustainable development through, inter alia, strengthening international environmental governance (IEG) and creating "clear links from the normative agenda to operational efforts" (Swedish EU Discussion Paper 2001: 4). The latter gave emphasis to "a strong focus on poverty eradication" and suggested that, due to a "growing gap between commitments and implementation", the "WSSD should have a focus on delivery" (UK Note 2001). Put differently, Sweden pressed for institution-building and action while Britain presented a toned-down version of the pragmatic and problem-solving approach that was also proffered by the USA. The UK position was designed to "address issues of wider concern" (ibid), highlighted the ideal of development, and favoured market-based instruments rather than simply pushing for environmental sustainability. "[W]e do not want institutional issues to dominate the Summit, distracting from achieving real action", it intoned (ibid.). A Europeanised version of this perspective won the day at Johannesburg because it was the least contentious, contained something positive for everyone, demonstrated some achievement, and could thus best survive the "difficult political backdrop" (Wallström 2002b) of the summit.

\footnotetext{
${ }^{1}$ This did indeed happen at the WSSD: the EU assembled a coalition for renewable energy which did not impose any stringent conditions and hence attracted a good number of signatories.

${ }^{2}$ Following the recognition of the Millennium Development Targets (MDGs) as a new master frame for sustainable development and the ongoing efforts of the WTO's Doha Development Agenda (DDA), Johannesburg's focus was plainly on poverty eradication (Bigg 2003). All this significantly reduced DG Environment's room for manoeuvre and opportunities for influence.
} 
Externally, the Union found itself with international negotiating parties that were either still distrustful of its objectives and credibility (G77 and China) or openly opposed to further institutional strengthening, financial commitments and principled language with normative implications (US and allied countries). The idea of a 'global deal' to reaffirm the 'spirit of Rio' and commit to action of a list of targets and timetables was thus seen as unattractive by either group. The US stance, in particular, had shifted over the previous years from obstructive passivity to principled opposition to many multilateral projects on the environment. ${ }^{1}$

The lack of international support underlined the central problem of many environmental negotiations - how to convince those parties who do not share the same priorities of the need for a comprehensive outcome package (Lightfoot and Burchell 2004: 341). The fundamental differences with the US position made this a valiantly futile effort indeed, but arguably, the global South could have been courted more effectively. Instead, when attempts at revitalising the Rio discourse floundered, the EU channelled its energy into defending the language and commitments of sustainable development accumulated over the past decade of IEG (Lightfoot and Burchell 2005: 89). This defensive posture may largely be blamed for the singular failure of addressing the topic of trade in any meaningful sense. The Doha Development Round, it appears, was on everyone's mind, but at the same time it remained curiously out of reach. In fact, as Bigg (2003) reports, due to US insistence on the primacy of the WTO, "there was a real danger that the message coming from Johannesburg would be that environmental policy should be subservient to economic policy". EU trade officials seemed to go along with this until the scheme ran into last-minute opposition from Ethiopia, Norway, and Switzerland (see Rosendal, this volume).

Despite this sobering assessment, it should also be recognised that defending the ideal of sustainable development against powerful contenders has been no small matter (Lightfoot and Burchell 2005: 89), especially at a time when the global agenda revolves around the MDGs. Besides the global conferences, however, the EU has had other opportunities to make greater progress, for instance with regard to institutional reform of environmental governance. In particular, the Commission on Sustainable Development (CSD) and the United Nations

\footnotetext{
${ }^{1}$ As Marsh (2005: 145) points out, "Recent years have seen environmental issues become a more prominent, recurring and frequently contentious agenda item in the transatlantic relationship."
} 
Environment Programme (UNEP) offer fruitful material for further analysis of the Union's role.

\title{
Commission on Sustainable Development: towards a practical politics
}

Established in 1993, the Commission on Sustainable Development (CSD) has a two-fold mission of continuous political dialogue and guidance for sustainable development policy. This made for an ambitious agenda and underlined its official status as the forum for UNCED follow-up activities (Mensah 1996; Chasek, this volume). The CSD's location under the ECOSOC umbrella should have perhaps given observers pause for thought. ${ }^{1}$ Being one of its functional commissions and equipped with no real political authority, legal powers or proper financial resources proved to be a heavy burden on the fledgling CSD (Wagner 2005: 107). It was, in other words, a doomed attempt to "maintain a high-profile leadership role on the Rio follow-up from a relatively low place in the institutional hierarchy" (Hyvarinen and Brack 2000: 25).

This was either done on purpose or through a temporary suspension of political acumen. Rio's positive spirit and a belief in the ultimate persuasiveness of sustainable development would explain US Vice-President Gore's description of the CSD's purpose as

\begin{abstract}
"focusing attention on issues of common interest; serving as a forum for raising ideas an plans; helping resolve issues that arise as nations proceed in their sustainable development agendas; monitoring progress; and helping shift the multilateral financial institutions and bilateral assistance efforts towards a sustainable development agenda (Bigg and Dodds cited in Wagner 2005: 103).”
\end{abstract}

This vision of consensual or at least cooperative problem-solving has not come to pass, for it underestimated the enormous political stakes inherent in the sustainable development agenda and the staying power of the North-South schism. ${ }^{2}$ Instead, the CSD developed into "another UN talk shop" (Agarwal et al. 2001: 170) where language served not as the medium of

\footnotetext{
${ }^{1}$ ECOSOC has for decades been on the sidelines of the UN system, even though it had originally been intended to be at the core of it - together with the General Assembly.

${ }^{2}$ In 2001, a Southern delegate deplored that - after ten years of negotiation - delegates were still not able to agree on "a satisfactory definition of sustainable development" (ENB 2001-04: 12). Given its notoriously ambiguous meaning and political usefulness, this should not have come as a surprise.
} 
dialogue and understanding, but of normative posturing and legalistic defensiveness. This dynamic has only begun to change for the better after a CSD reform was agreed at Johannesburg.

The CSD posed another problem because it was an elective body in which not all the member States would be present. It took until the second session to resolve the issue of EC participation. This involved the granting of speaking rights, the rights to put propositions but not to vote on the understanding that there would be no increase in the representation to which Member States were already entitled (Mensah 1996: 32). Of the 53 elected state members of the CSD, there have generally been eight or nine EU participants. France, Germany and the United Kingdom have been present at all the sessions up to date ${ }^{1}$, which shows that they have taken the new forum very seriously and aim to influence the EU position through their direct access to the discussions.

The Union only attained the status of 'full participant' (without the right to vote) in February 1995 and has traditionally relied on a 'lead-country' approach in the CSD (Vogler 2003: 66; Cameron 2004: 162). This flexible arrangement means that the current Presidency of the European Council will articulate the common EU position while leaving specific issue-areas (e.g. freshwater) to particular member states who have accumulated expertise or a heightened interest in the matter. The result has been a broadly consistent and competent advocacy role of the Union. Many EU countries had been among the chief instigators of the CSD at UNCED and consequently, the EU position has often been proactive and forward-looking. The CSD bears the norm of sustainable development in its name and was hoped to become the primary 'watchdog' over its progressive integration into UN and affiliated institutional policies. After UNGASS 1997, the EU began to argue for a re-orientation of the CSD towards a more pragmatic, goal-oriented purpose - a plea that was shared by other delegations at Johannesburg and resulted in a noticeable institutional overhaul.

In 1994, when the CSD held its first genuine meetings, EU statements already revealed a certain 'practical' outlook, for instance when the Greek Presidency declared that "CSD decisions must be short and action-oriented and political impetus is vital" (ENB 1994). Several months later, the German Presidency added that "the CSD needs dialogue instead of debate and an integrated approach to the inter-related questions of sustainable development"

\footnotetext{
${ }^{1}$ UN Department of Economic and Social Affairs, Division for Sustainable Development, Record of CSD Members and Bureau (1993-2006),http://www.un.org/esa/sustdev/csd/csdolmem.htm
} 
(ENB 1994). There is a sense of political weariness here that would only increase further as the years went by. From a European perspective, the CSD's task was to implement, and not re-negotiate, the Rio agenda. Dialogue, if based on a consensual understanding, was welcome, but long-winded and principled debates were not. The normative grid had been laid at Rio and its continued political scrutiny would slow down or even undermine the European project of global sustainable development.

This thinking informed the EU's strategy in the CSD. However, after UNGASS the voices calling for action and implementation grew louder. From 1998 onwards, the EU concerned that nothing was being done on the ground - began pressing for more stringent national reporting requirements and ultimately even for monitoring arrangements (e.g. ENB 1998; ENB 2003; ENB 2005). ${ }^{1}$ The governments of the global South responded with dismay and made sure that UNGASS foundered on the rocks of distrust and bitterness. European negotiators started to realise that the "global partnership for sustainable development" was losing acceptance (ENB 1997), but there was little they could do in the short run ${ }^{2}$. Towards the new millennium, however, the negative trend in official development assistance (ODA) was gradually being reversed. EU initiatives on freshwater and energy that had stalled during the acrimonious rifts of 1997-98 became a realistic proposition and Northern countries in general began to look for the 'pragmatic' de-politicisation of the CSD which had been naively assumed, rather than devised, at its inception.

The Union has certainly cultivated what Wagner (2005: 112) has called a "driving strategy": having assiduously prepared its positions and alternative arguments before the meetings, the EU "often presents action proposals rather than solely responding to others' suggestions." Under the guise of such forward-looking and often "problem-solving" proposals (Wagner 1999) the EU has sought to dominate the political agenda and direct the debate away from political principles towards the practical implementation of sustainable development. Despite the sincere intentions behind this tactic, the strategic, political impact should not be underestimated. So successful was the Union's 'driving strategy' that, in a 2001 expert group on energy questions, several G77 delegates complained that the Chair's negotiating text mostly reflected "European perceptions of the energy issue" (ENB 2001b: 7). This example

\footnotetext{
${ }^{1}$ This agenda was later complemented by a common Northern appeal for 'good governance' to ensure the effective spending of money, the respect of human rights, and a certain measure of transparency (ENB 2005: 4).

${ }^{2}$ Environmental ministries and the EU's DG Environment are not in control of the national budgets. Their priorities, despite the EU's official Rio commitments, were way down the list of finance ministries.
} 
demonstrates that the EU's desire for policy and norm diffusion was not only relatively influential, but also that it frequently collided with the wishes of watchful counterparts.

Overall, it is obvious that the attempts at indirect agenda-setting and de-politicisation were more successful than direct proposals for national regimes of implementation and monitoring. Joining forces with the JUSCANZ group led by the USA at Johannesburg, the EU achieved a considerable reform of the CSD. The new plan allowed for a review year between fully-fledged CSD negotiation sessions and stepped up the involvement of technical experts, civil society and industry groups. ${ }^{1}$ The CSD's first review session in 2004 is a good illustration of a waning North-South schism. Its agenda was very close indeed to the EU's preference of having just a handful of topics for each negotiation cycle. The meeting itself was dominated by experts exchanging their experiences about the problems they faced in implementing specific local projects. Weighty political issues such as global trade immediately lost much of their salience in this new, 'pragmatic' context. In fact, the subject of trade was not even broached.

In sum, the CSD is approaching the EU's objective of being a forum for practical implementation and a loudspeaker for sustainable development. A Swedish EU discussion paper (2001: 5) had spelt out a number of desirable reforms ${ }^{2}$. The other EU Member States appear to have agreed on this direction and the reformed CSD came quite close to incorporating the desired aspects. This also demonstrates the structural power and diplomatic perseverance of the EU as an international actor. Yet ultimately, the CSD is still solely a small piece in the jigsaw of GEG. Apart from the global conferences on environment and development, the Union has focused most of its attention on strengthening the status of UNEP. The intuition behind this project is that the concept of sustainable development becomes hostage to diverse interests unless there is a strong environmental sector clamouring for environmental sustainability ${ }^{3}$.The transformation of UNEP into a specialised agency, the United Nations Environment Organisation (UNEO), could create a new, potent environmental supervisory body.

\footnotetext{
${ }^{1}$ This was at the expense of what some called the "New York mafia" (ENB 2001c: 12) of seasoned diplomats with little grasp of or interest in matters of practical implementation.

${ }^{2}$ It recommended a "focus on the practical/technical level", a "high level segment every second year", a limited thematic work programme, targets and indicators, the exchange of practical experiences regarding the implementation of Agenda 21 and further "development of multi-stakeholder dialogue".

${ }^{3}$ In contrast to what some may have assumed at the time of UNCED, sustainable development does not replace the environment as political priority - it rather presupposes the latter in order to function appropriately.
} 


\section{UNEP: edging forward inch by inch}

Since the creation of UNEP at the 1972 UN Conference on the Human Environment, it has counted the EU among its staunchest supporters. This backing has been visible both by the disproportionate amount of funding provided and by the EU's consistent endorsement of institutional strengthening and a secure financial base for UNEP. The optimism of the early 1990s and the Rio summit gave rise to a stronger and more self-confident environmental organisation that found itself at the forefront of new political initiatives, though it has at times looked overburdened with the growing number of demands placed on it. The UNEP Governing Council and its GMEF formation are composed of 58 governments elected by the General Assembly for a four-year term on the basis of 'equitable regional representation'. For 2006-7, this has meant that twelve EU Member States are present. ${ }^{1}$ The Community only enjoys observer status, but collaborates with the organisation under the terms of a 'Memorandum of Understanding' signed in 2004 by the EU Environment Commissioner and the UNEP Executive Director. The EU and its Member States are the most significant donors to UNEP's Environment Fund ${ }^{2}$, with both the UK and Netherlands contributions ranking above that of the USA and other Member States occupying eleven places amongst the top twenty donors ${ }^{3}$.

UNEP's "peculiar dual mandate" (Imber 1993: 58) of being both catalyser and coordinator has indeed been the source of persistent practical headaches. Its comparatively small budget (60 million US-Dollars in 2000) means that it cannot aspire to be a "delivery agency" (Dodds 2000: 294), but has to rely on scientific fact-finding, persuasion, and advances in international environmental law. This catalytic role has been assumed with surprising success (Najam 2003), although it does not measure up to the much greater European ambitions of creating a strengthened and more unified system of environmental governance. Nor is the lack of coordinative muscle a historical accident of ad hoc regime creation (Najam 2003: 372)

With regard to the EU's plans for a strong environmental pillar in the UN system, there were only two positive options available (Imber 1993). One would have been to redistribute

\footnotetext{
${ }^{1}$ Austria, Belgium, France, Germany, Netherlands, Sweden and the UK from WEOG and Bulgaria, Czech Republic, Hungary, Poland and Romania from the East European Group.

${ }^{2}$ On US contributions, see Chasek (this volume).

${ }^{3}$ Cumulative contributions for 2004-6 were UK - \$ 23.5 m., Netherlands - \$ 18.29 m, USA \$ 18.23. http://www.unep.org/rmu/en/financing_of_UNEP/Environment_Fund/Table_Major_Don...
} 
the coordination mandate to other institutions and concentrate on the catalytic potential. This has actually happened to some extent, for the CSD and the Environment Management Group (EMG), set up in 1993 and 2001 respectively, have been entrusted with mainstreaming sustainable development and environmental aspects. The second option was to recast UNEP as a specialised agency with increased funding and strengthened authority. It is this latter objective which has now become the Union's official agenda for GEG. But between Imber's initial analysis in 1993 and EU's public commitment to a UNEO lay at least eleven years filled with a succession of institutional proposals and tactical moves.

The period between Rio and UNGASS in 1997 is today known as the 'dark hour' of UNEP as an organisation ${ }^{1}$. A number of states (including Germany, South Africa, Singapore, Brazil) came to UNEP's rescue at the summit and proposed the creation of a World Environment Organisation (WEO) (Dodds 2000: 302). However, neither had they sufficiently prepared their initiative, nor were most countries willing to contemplate the financial resources required for this reform. It was perhaps a brave proposition, but the timing could not have been much worse.

Only one year later, the UN Task Force on Environment and Development recommended the establishment of an 'Environment Management Group' (EMG) that would be chaired by UNEP's Executive Director and involve many other UN bodies and affiliated financial institutions (Hyvarinen and Brack 2000: 32). Finally, in 2001, the EMG was indeed set up and charged with improving "UN system-wide inter-agency coordination related to specific issues in the field of environment and human settlements through a comprehensive series of measures designed to enhance coherent and coordinated action within the UN system in these areas" (EMG 2006). The EU often expressed its "high hopes" for the EMG (EU Presidency Statement 2000, 2001a), regarding it as "a first step in the right direction" (Environment Council 2000). After a few years, the realisation has set in that the EMG "has not met expectations, suffering from a relatively weak mandate and status" (EU Speaking Points 2006a). ${ }^{2}$

\footnotetext{
${ }^{1}$ Some observers argued that the UNCED mandate reaffirmed UNEP as the main environmental organisation and gave it more responsibilities than ever before (Timoshenko and Berman 1996: 45). Yet, whereas political attention focused on the newly created CSD and developing countries grew increasingly restless in the face of Northern refusal to honour financial promises, UNEP was additionally burdened by a wavering leadership. By the time of UNGASS, it had been labelled as largely irrelevant (ENB 1999: 11).

${ }^{2}$ However, like in the case of the CSD, the Union is not ready to discard this instrument. Seeing it as part of an overarching framework of GEG reform, a more powerful EMG, backed up with a mandate from the Global
} 
The supposed remedy, an overarching European project of GEG reform, gradually took shape in the run-up to the Johannesburg summit in 2002. With the CSD in crisis and the norm of sustainable development coming under renewed pressure, the constitution of an environmental pillar within the UN system was deemed the best way forward. Official EU statements during this time were still phrased in quite general terms. Pointing out UNEP's financial problems and its lack of authority, the Swedish Presidency referred to further EU proposals "for a greatly improved coordination under the aegis of UNEP of all relevant institutions to harmonise activities on a thematic basis" (EU Presidency Statement 2001b). ${ }^{1}$

Meanwhile, political debates in UNEP were already raging. Having renewed their commitment to Agenda 21 and professed their faith in UNEP as an institution in the Malmö Declaration of May 2000, the members of the Governing Council (GC) gave a new lease of life to this beleaguered institution. Moreover, the EU, acting in concert with China and Hungary, had convinced participants to begin convening an annual high-level ministerial forum - the Global Ministerial Environment Forum (GMEF) - alongside the GC meetings (ENB 1999: 10) ${ }^{2}$. But the EU's ambitions did not stop there. When UNEP commenced preparing its input for the WSSD, the EU proposed an ad hoc intersessional working group for the review of options to strengthen GEG (ENB 2001a: 4). ${ }^{3}$

The views of the major negotiating partners in this working group crystallised soon. The US could not agree with the ideas of improving coherence and enhancing integration of governance institutions. It maintained that "the US does not believe that current IEG is incoherent" (ENB 2001e:5), suggested that alleged 'fragmentation' and competition in the system was better seen as 'healthy tension' (ENB 2001d: 2), and contested a strengthened mandate for the GMEF. ${ }^{4}$ This obstructionism prompted an exasperated Swiss delegation to demand: "'Why are we here?" (ENB 2002: 5). The other major negotiating bloc (G77 \&

Ministerial Environmental Forum, could address issues in need of horizontal coordination and even instruct the United Nations Development Group (UNDG) (EU Speaking Points 2006b).

${ }^{1}$ The Environment Council (2001) ventured even further by submitting that the gradual adaptation of UNEP "could ultimately lead to a World Environment Organisation, respecting existing headquarters".

${ }^{2}$ The US was mildly in favour of this idea, for they counted on the GMEF to reign in the bureaucratic power of UNEP officials (Rosendal, this volume).

${ }^{3}$ The group met six times in total and held its last meeting at the seventh Special Session of the GC in February 2002. The negotiations witnessed an eventual polarisation of positions, with the EU changing the focus of its reform proposals when it met an insurmountable impasse.

${ }^{4}$ At the heart of US opposition was a straightforward rejection of greater codification and coherence which might eventually lead to regimes of monitoring and compliance or pose a threat to the WTO trading order by engaging in regulatory competition with it. 
China) was only slightly more cooperative. ${ }^{1}$ Lingering distrust of an environmental and potentially anti-development agenda played as much a role here as the fear of greater monitoring competencies which could highlight countries' lack of implementation and undermine their national sovereignty.

The EU thus found itself confronted with truly formidable diplomatic opposition and gradually ceased talking about a WEO or UNEO. Turning towards a more incremental strategy, European negotiators concentrated on upgrading the status of the GMEF and called for universal membership of the GC which, they hoped, would ultimately lead to a natural demand for the GMEF's executive powers. G77 \& China were not so easily distracted, however, with Nigeria challenging supporters of an upgraded GMEF "to come straight out and say that they want a new global environmental body" (ENB 2001e: 5).

At the final meeting in February 2002, the EU, a handful of allies, and their plea for extensive reform - including compliance monitoring, co-location of MEA secretariats and a stronger GMEF - faced a US-G77 coalition which opposed language about UNEP's enhanced role, the idea of a UNEO, and kept referring the issue of better coordination back to the EMG (ENB 2002). Interestingly, the EU still left this session with mild satisfaction and an optimistic perspective for Johannesburg. This may have been the quiet contentment of a normative power confident of its leadership: after all, apart from the G77's insistence on strengthening UNEP's original mandate (ENB 2002: 11), there were no serious alternative offers on the table. The search for allies could be a longer-term quest as long as the direction of reform proposals was right.

European optimism was not borne out by the WSSD and its Johannesburg Plan of Implementation (JPI). Although, as Commissioner Wallström (2003) rightly stated, the Union "did manage to reconfirm the need for international co-operation to address global sustainability challenges", the JPI merely gave a nod in the direction of institutional reform and invited UNGA to consider universal membership of UNEP's GC. Arguably as a result of this relative defeat, by late 2004 and hence in time for the Millennium Review Summit in September 2005, the EU had adopted a new negotiating objective. If, at the $8^{\text {th }}$ Special Session of the GC in April 2004, the case for a specialised agency (UNEO) was "deftly kept

\footnotetext{
${ }^{1}$ It supported a moderate strengthening of UNEP, including greater financial resources and better coordination of MEAs (ENB 2001d). Nonetheless, G77 also insisted on keeping the GMEF dependent on the GC and resisted any move towards a specialised agency (UNEO) or WEO.
} 
afloat by France in the margins of various meetings" (ENB 2004: 8), it was already being discussed by a working group of interested countries (Lenzerini 2006; France-Diplomatie 2006) and was soon elevated to the status of a common EU reform proposal. ${ }^{1}$

At the same time, efforts were underway to hone the arguments in favour of universal membership. At an international round table organised by the German government and the think tank Ecologic, arguments for this particular reform were debated and improved. Participants emphasised that a common view on GC membership was essential in order to "not allow divisions within the EU to weaken its position" and "prepare the EU to speak clearly and with one voice" at the upcoming meetings (Ecologic Round Table 2004: 2-3). ${ }^{2}$

The UNEO motion had become so attractive for EU policy-makers because it offered a compromise between the options of a moderately strengthened UNEP without much coordinative power and a fully-fledged WEO with all its problems of legitimacy and acceptability. A UNEO would represent an umbrella organisation for the numerous MEAs and it would thus achieve some much-needed rationalisation in GEG (Lenzerini 2006). The EU took this scenario to the UN World Summit 2005 where it sought to graft it onto the environmental aspects of the Secretary-General's report 'In Larger Freedom' from March 2005. This report was based on a 2004 report by the UN High-Level Panel on Threats, Challenges and Change which marked a conceptual shift by defining international security above all as human security. ${ }^{3}$

Having perused successive drafts of the World Summit's Outcome Document, Morgera and Duran (2006) conclude that the EU managed to considerably raise the number of references to sustainable development. However, while a June draft made explicit references to aspects of environmental governance, such as a coherent institutional framework with better coordination and monitoring, the final outcome merely included a section on 'Environmental Activities' and only promised to "explore the possibility of a more coherent

\footnotetext{
${ }^{1}$ The European Council in June 2005 proposed to initiate a process of institutional reform "which will lead to negotiations on the establishment of a UN agency for the environment" which, equipped with adequate funding and equal status to other specialised agencies, would help to mainstream the environmental dimension of sustainable development more effectively and consistently (European Council 2005: 11).

${ }^{2}$ These efforts, however, were clearly part of an incremental strategy that aimed at obtaining realistic concessions from negotiating partners who were unlikely to sign up to a UNEO. Universal GC membership, as the round table document timidly mentioned, would "provide an additional impetus for reform of the governance structure" (Ecologic Round Table 2004: 3) and hence represent a first step forward.

${ }^{3}$ It also "had the undisputable value of injecting for the first time environmental issues into the security dialogue, specifically focusing on climate change" (Morgera 2006: 17) - two innovations that chime very well with the Union's own new discourse on security.
} 
institutional framework to address this need" (ibid: 17). It does, however, incorporate "respect for nature" in the section on principles and values and confirms sustainable development as "a key element of the overarching framework of United Nations activities", reproducing the language used in the JPI (Morgera 2006: 19).

Recalling UNEP's stalled debate on institutional reform, one should not be too surprised about a modest outcome that primarily recycles agreed language from previous documents. The Union certainly made a strong case both for universal membership of the GC and for an indicative scale of contributions for the financing of UNEP - even before explicitly stating the objective of a UNEO in the run-up to the 2005 World Summit. Despite no enhancement of its mandate, the mere existence of the GMEF and its regular pronouncements - not least about the link between the environment and the MDGs - have already given UNEP a stronger voice on the international scene. ${ }^{1}$

Finally, it is encouraging to observe that, on all matters of environment and sustainable development, the EU spoke with a single voice at the 2005 World Summit, thus acting as a "unified negotiating bloc" for its 25 members and an additional 9-11 associated countries (Morgera and Duran 2006: 20). Genuine influence or impact, however, is not only measured in terms of argumentative unity displayed at the negotiating table. It reaches much deeper, both temporally and structurally.

\section{Conclusion}

The preceding analysis has established, albeit imprecisely, that the EU has exercised influence at least in the setting of agendas if not in delivery, although this may sometimes fall short of its self-proclaimed leadership role. This is consistent with its recent performance in other areas of global environmental governance, in the promotion of norms such as the precautionary principle and most significant of all, in the rescue of the Kyoto Protocol and the establishment of an international emissions trading system (Vogler 2005; Zito 2005).

\footnotetext{
${ }^{1}$ In a 'constructivist' fashion, the ENB (2005: 10) explains this through the growing importance of its "soft law statements". And it is perhaps the European Council that served the EU as a model for its preferred, strengthened version of the GMEF.
} 
There is a structural basis for EU influence as an actor which may be conceptualised in terms of its 'presence' in the international system. ${ }^{1}$ That is to say the sheer scale of the Single Market and the range of EU internal policies will have a profound and sometimes magnetic effect upon outsiders, particularly those which are close trading and aid partners and are located within the European region. This creates expectations that the EU will act and also ensures that EU positions in multilateral forums will be followed by states who have, or wish to have, a 'membership perspective' and to a certain extent by the dependent ACP countries. It is reinforced by the Union's commitment to multilateralism and its enthusiasm, as demonstrated in the range of countries contributing to ESDP operations. Since the 1980s, the Union's attempts to assert itself in international environmental affairs have been assisted by changes in the opportunity structure. The ending of the Cold War and continuing difficulties with Soviet and Eastern Bloc recognition of the EC and the abdication by the United States of its previous leadership role have have been significant (cross reference Chasek this vol)). When faced with an obstructionist US and a coalition of G77 \& China primarily interested in winning more financial and economic commitments and protecting their national sovereignty, it is not difficult to present oneself as the leader on the global environmental stage.

In specific negotiations, internal unity is at first sight a critical precondition of 'actorness' and influence. European leadership, Marsh (2005: 157) argues, is “proportional to its internal unity" whose degree, in turn, can often be discerned through the mandate conferred by the European Council or by carefully reading the Presidency statements reflecting a common EU position. The implication here is that the major problem is one of persuading 27 Member States to take a consistent line. The sheer number and variety of Member States is, indeed, daunting and there are opportunities for outsiders to exert influence by proxy, for instance by relying on a sympathetic "Trojan horse" that largely shares their views (Rhinard and Kaeding 2005: 9). The restricted membership of the CSD and UNEP Governing Council limits the numbers but there will always be the need for co-ordination meetings which mean that EU delegations have to get up early in advance of conference sessions and 'the Nordics have to get up even earlier' .(cross reference to Rosendal). ${ }^{2}$

\footnotetext{
${ }^{1}$ The concepts of 'presence' and 'opportunity' as the foundations of 'actorness' are derived from Bretherton and Vogler (2006) and are applied to external environmental policy in Chapter 4.

${ }^{2}$ Typically, Nordic meetings including Norway precede EU co-ordination meetings. When asked about the influence of the Nordic group, a Commission official responded: 'we are not supposed to know about that!' (Interview, Commission,2006).
} 
The problem of consistency between Member States themselves and the Commission ought not to be exaggerated. One of the key ways in which the EU must be distinguished from alliances such as the G77 or JUSCANZ is that it possesses a robust set of internal procedures and a supranational Commission. The difference is especially clear when the Union is acting on issues within exclusive community competence where the Commission has exclusive rights of initiative and to represent the Union as a whole and where, in all probability, qualified majority voting can be used to settle differences. Even when competence is held by the Member States, the presidency and the Council Secretariat provide structure and the Commission can act as a 'sheep-dog' to round up wavering Member States although the problems of co-ordination are sometimes 'horrendous' (Interview Commission 2006). Furthermore, individual members have tended to specialise in particular issues and have played the role of 'lead states'. In the environmental area policy has not been reduced to the lowest common denominator of agreement amongst the Member States, rather there is substantial evidence that 'lead states' have managed to raise the general level of ambition. Contrary to some expectations, the 2004 enlargement did not have a proportional effect upon the problem of co-ordination. Most of the new Member States are relatively small and 'cannot afford to send delegations of more than one person (if that) to conferences and the larger states rarely have more than one or two people and do not say much' (Interview Commission 2006). Finally, questions of GEG are not likely to prove as divisive as those that concern Member States dealing with the politics of trade agreements where very specific national commercial interests are at stake (for example agricultural subsidies in the Doha Round or Chinese textile exports in mid 2005) or indeed in the CFSP where serious differences in political orientation sometimes prevent united action.

\section{I}

The EU is in some ways comparable to a large federal state insofar as its external policy effectiveness may be compromised by internal 'incoherence'. During the WSSD, there certainly was a significant division between the EU sectors of trade and the environment which led to the ultimately unsuccessful attempt at subordinating MEAs to the WTO. And Britain most likely worked behind the scenes to achieve a more 'pragmatic' result focused on flexible implementation mechanisms, which emphasised the role of private actors and publicprivate partnerships. Similarly, in the preparations for UNCED, a preoccupation with trade issues and the importance of the Uruguay Round over-rode environmental considerations. There are still differences in the interpretation of sustainable development between the sectors of development and environment. As Opoku and Jordan (2005: 22) put it, "[t]he one language 
of sustainable development is in this case perhaps only thinly veiling two still separate cultures."

To be a credible leader - in the eyes of the developing world in particular - the Union has to get its internal policies right and create linkages with a coherent set of external policies. Those carrying the message of environmental protection and sustainable development onto the global stage should be able to show how they themselves have realised this project at home (Wallström 2002a; Solbes 2001). Secondly, the EU's external policy should reflect its international commitments, ranging from a long-standing aim to increase ODA to the impact of its trade or agricultural policies. It is critical here that the EU position is not seen in terms of "double standards", "neo-colonialism" or otherwise primarily self-interested strategy (Morgera and Duran 2006: 21). A year after the WSSD, Commissioner Wallström (2003) with her memory of negotiations still fresh - repeatedly stressed that her priority was "policy coherence between external commitments and internal policies."

In a sense, the analysis of the Union's deficiencies has thus come full circle by referring us back to its internal policy-making. Achieving the coherence Wallström demands would necessitate the creation of a relative harmony of purpose within the EU. But the constant compromises, corrections and even turn-arounds (e.g. with regard to ODA) undertaken to continue the at least tripartite mission of economic competitiveness, agricultural preservation and sustainable development result in a serious "role ambiguity" and "perceived inconsistency" (Chaban et al. 2006: 254) that saps the incipient credibility. And while there can often be large differences in framing environmental issues between the various Council formations, it is the European Council which is charged with synthesising these positions. Taking account of the various agendas, it seeks to reassure everyone around the table, which tends to produce an often ambivalent negotiation mandate.

Consequently, our observations of EU influence in process of GEG reform are less the result of immaculate European strategising, unity of purpose or its powers of persuasion. Perseverant and intelligent agenda-setting may have played as much a role as contextual factors like the absence of serious competition. By putting forward principles and norms like sustainable development and precaution and by insisting on institutional movement towards more coherence, authority and coordination, the EU is often "able to define the international problem and provide a plausible solution early enough in the process to gain the advantage 
over other actors" (Zito 2005: 372). And when the Union comes up against more proactive opposition - such as the attempts to renegotiate parts of Agenda 21 at Johannesburg - it generally proves itself to be a formidable blocking power, which is undoubtedly helped by its lack of negotiating flexibility arising from problems of co-ordination once the mandate has been defined.

Leadership, regardless of how precisely it is created and sustained, does of course not always equal real influence. The latter's litmus test is perhaps rather the transition of other actors to different values (Lightfoot and Burchell 2005: 87) or a marked "redistribution of values" that Sjöstedt et al. (2005: 300) failed to find with regard to the historical record of GEG. On the other hand, there are also some signs that the Union's tenacity in fine-tuning tactics and arguments may finally be paying off. At the 2006 annual UNEP meeting, some observers felt that the principled opposition of important countries, such as Japan and China, to a UNEO may be weakening (ENB 2006: 14; Rosendal, this volume). Perhaps this also demonstrates that the often inflexible negotiating performance of the EU and the complex status of its actorness are not among its major deficiencies. Credibility and coherence should be the objectives for a stronger, more effective Union on the international stage. Much harder to 'fix' than organisational or strategic aspects, they arguably represent the real challenge for the EU in today's global environmental governance. 


\section{Bibliography}

Agarwal, Anil et al. (eds.) (2001), Poles Apart, New Delhi: Centre for Science and Environment.

Bretherton, Charlotte and John Vogler (2006), The European Union as a Global Actor, Abingdon \& New York: Routledge.

Brenton, Tony (1994) The Greening of Machiavelli: The Evolution of International Environmental Politics, London:RIIA/Earthscan.

Cameron, Fraser (2004), “After Iraq: The EU and Global Governance”, Global Governance, Vol. 10, pp. 157-163.

Chaban, Natalia et al. (2006), "The European Union As Others See It", European Foreign Affairs Review, Vol. 11, pp. 245-262.

Chasek, Pamela S. (2000), “The UN Commission on Sustainable Development: The First Five Years" in: Pamela S. Chasek (ed.), The Global Environment in the 21st Century:

Prospects for International Cooperation, Tokyo: UNU Press.

Danish Non-Paper (2001), "World Summit on Sustainable Development - 'A Global Deal'", 02 October, URL= http://www.anped.org/PDF/WSSD\%20EU\%20papers.pdf [06/10/2006].

Dimas, Stavros (2005), Intervention by Stavros Dimas, Commissioner for Environment European Commission at the 13th Session of the Commission on Sustainable Development, High Level Panel discussion, New York, 20 April, URL= http://www.europa-euun.org/articles/sk/article_4619_sk.htm [20/10/06].

Dodds, Felix (2000), "Reforming the International Institutions", in: Felix Dodds (ed.), Earth Summit 2002: A New Deal, London: Earthscan, pp. 291-314.

ECOFIN Council (2002), Council Conclusions, $2432^{\text {nd }}$ Council meeting, Luxembourg, 4 June.

Ecologic Round Table (2004), "UNEP - Establishing Universal Membership", Summary of the Chairman, 2-3 February, Cecilienhof, Potsdam, Germany, URL= http://www.ecologic.de/download/projekte/1800-1849/1810/1810_Summary.PDF [18/10/06].

ENB (1994), Summary of the Second Session of the Commission on Sustainable Development, 16-27 May, URL= http://www.iisd.ca/vol05/0525078e.html [17/10/06].

ENB (1994), UN General Assembly Highlights, 19-21 October, URL= http://www.iisd.ca/vol03/0305002e.html [17/10/06].

ENB (1997), Summary of the Nineteenth United Nations General Assembly Special Session to Review Implementation of Agenda 21, 23-27 June, URL= http://www.iisd.ca/vol05/0588010e.html [17/10/06].

ENB (1998), The Sixth Session of the Commission on Sustainable Development, 20 April - 1 May. 
ENB (2001a), Summary of the $21^{\text {st }}$ Session of the UNEP Governing Council and Second Global Ministerial Environment Forum, 5-9 February.

ENB (2001b), Summary of the Second Session of the Ad Hoc Intergovernmental Group of Experts on Energy and Sustainable Development, 26 February - 2 March.

ENB (2001c), Summary of Ninth Session of the Commission on Sustainable Development, 16-28 April.

ENB (2001d), Summary of the Second Meeting of the Open-Ended Intergovernmental Group of Ministers or Their Representatives on International Environmental Governance, 17 July.

ENB (2001e), Summary of the Fourth Meeting of the Open-Ended Intergovernmental Group of Ministers or Their Representatives on International Environmental Governance, 30

November - 1 December.

ENB (2002), Summary of the Seventh Special Session of the UNEP Governing Council, Third Global Ministerial Environment Forum and Final Open-Ended Intergovernmental Group of Ministers or Their Representatives on International Environmental Governance, 12 -15 February.

ENB (2003), Summary of the Eleventh Session of the Commission on Sustainable Development, 28 April - 9 May.

ENB (2005), Summary of the Thirteenth Session of the Commission on Sustainable Development, 11-22 April.

ENB (2006), Summary of the International Conference on Chemicals Management and Ninth Session of the UNEP Governing Council/Global Ministerial Environment Forum, 4-9 February.

Environment Council (2000), Council Conclusions, 2321 ${ }^{\text {st }}$ Council meeting, 18-19 December.

Environment Council (2001), Council Conclusions, 2355 ${ }^{\text {th }}$ Council meeting, 7 June.

Environment Management Group (EMG) (2006), URL= http://www.unemg.org/about.php $[15 / 10 / 06]$

EU Presidency Statement (2000), Statement by Mrs Catherine GRAS, Financial Adviser at the Permanent Mission of France to the United Nations, 18 October, New York, URL= http://www.europa-eu-un.org/articles/en/article_192_en.htm [19/10/06].

EU Presidency Statement (2001a), Statement by Mr. Jean-Paul Charlier, Representative of Belgium, on behalf of the European Union, 25 July, URL= http://www.europa-euun.org/articles/en/article_187_en.htm [19/10/06].

EU Presidency Statement (2001b), Meeting of UNEP Open-Ended Group of Ministers on International Environmental Governance, Statement by Mr. Kjell Larsson, Swedish Minister for the Environment on behalf of the European Union, 18 April, New York, URL= http://www.europa-eu-un.org/articles/en/article_315_en.htm [19/10/06]. 
European Commission (2003), The European Union and the United Nations: The choice of multilateralism, COM(2003) 526 final.

European Council (2005), Presidency Conclusions, Brussels, 16-17 June.

EU Speaking Points (2006a), Informals of the General Assembly on Environmental Reform, Statement by Ambassador Gerhard Pfanzelter, Permanent Representative of Austria to the United Nations, on behalf of the European Union, 19 April, New York, URL= http://www.europa-eu-un.org/articles/en/article_5936_en.htm [19/10/06].

EU Speaking Points (2006b), Informal Meeting of the General Assembly on Environmental Reform, Statement by Counsellor Alice Zaunschirm, Austrian Mission to the United Nations, on behalf of the European Union, 13 June, New York, URL= http://www.europa-euun.org/articles/en/article_6052_en.htm [19/10/06].

France-Diplomatie (2006), "Transformer le PNUE en agence spécialisée", URL= http://www.diplomatie.gouv.fr/fr/actions-france_830/onuorganisationsinternationales_1032/institutions-specialisees-onu_3187/onueenvironnement 4347/ [15/10/06].

Hyvarinen, Joy and Duncan Brack (2000), Global Environmental Institutions: analysis and options for change, Report prepared for the Department of the Environment, Transport and the Regions (UK), London: Royal Institute of International Affairs.

Imber, Mark (1993), "Too many cooks? The post-Rio reform of the United Nations", International Affairs, Vol. 69, No. 1, pp. 55-70.

Jordan, Andrew and Heather Voisey (1998), "The 'Rio Process': The Politics and Substantive Outcomes of 'Earth Summit II'", Global Environmental Change, Vol. 8, No. 1, pp. 93-97.

Lenzerini, Federico (2006), "The Reform of Environmental Governance in the United Nations: the French Proposal", in: The Future of Environmental Law: International and European Perspectives, European University Institute (EUI) Working Papers Law No. 2006/01, pp. 12- 14.

Lightfoot, Simon and Jon Burchell (2004), "Green hope or greenwash? The actions of the European Union at the World Summit on sustainable development, Global Environmental Change, Vol. 14, No. 4, pp. 337-344.

Lightfoot, Simon and Jon Burchell (2005), "The European Union and the World Summit on Sustainable Development: Normative Power Europe in Action?", Journal of Common Market Studies, Vol. 43, No. 1, pp. 75-95.

Marsh, Duncan R. (2005), "Friends and Foes: industrialised countries in multilateral environmental negotiations", in: Angela C. Kallhauge, Gunnar Sjöstedt, Elisabeth Corell, Global Challenges: Furthering the Multilateral Process for Sustainable Development, Sheffield: Greenleaf, pp. 144-170.

Mensah, Chris (1996), “The United Nations Commission on Sustainable Development”, in: Jacob Werksman (ed.), Greening International Institutions, London: Earthscan, pp. 21-37. 
Morgera, Elisa (2006), "The 2005 World Summit: UN Reforms and the Protection of the Environment", in: The Future of Environmental Law: International and European Perspectives, European University Institute (EUI) Working Papers Law No. 2006/01, pp. 1520.

Morgera, Elisa and Marin Duran (2006), "The 2005 UN World Summit, the Environment and the Role of the EU: Priorities, Promises, and Prospects", RECIEL, Vol. 15, No. 1, pp. 11-22.

Najam, Adil (2003), “The Case Against a New International Environmental Organization”, Global Governance, Vol. 9, pp. 367-384.

Opoku, Camilla and Andrew Jordan (2005), "The European Union and the External Dimension of Sustainable Development: Ambitious Promises but Uncertain Outcomes", Paper prepared for the 2005 Berlin Conference on the Human Dimensions on Global Environmental Change "International Organisations and Global Environmental Governance", Potsdam, 2-3 December.

Rhinard, Mark and Michael Kaeding (2005), "The International Bargaining Power of the European Union in 'Mixed' Competence Negotiations: The Case of the 2000 Cartagena Protocol on Biosafety", Paper presented at the European Union Studies Association (EUSA) Conference 31 March - 2 April, Austin, Texas, United States.

Sjöstedt, Gunnar, Lisa van Well, and Angela C. Kallhauge (2005), “An evolving sustainable development regime", in: Angela C. Kallhauge, Gunnar Sjöstedt, Elisabeth Corell, Global Challenges: Furthering the Multilateral Process for Sustainable Development, Sheffield: Greenleaf, pp. 294-304.

Solbes, Pedro (2001), Pedro Solbes comments on "Sustainable Development" at the OECD Ministerial meeting in Paris, 17 May, URL= http://www.europa-euun.org/articles/en/article_128_en.htm [20/10/06].

Swedish EU Discussion Paper (2001), "International Governance for Sustainable Development", December 2001, URL= http://www.anped.org/PDF/WSSD\%20EU\%20papers.pdf [06/10/2006].

Timoshenko, Alexander and Mark Berman (1996), "The United Nations Environment Programme and the United Nations Development Programme”, in: Jacob Werksman (ed.), Greening International Institutions, London: Earthscan, pp. 38-54.

UK Note on the World Summit on Sustainable Development (2001), October 2001, URL= http://www.anped.org/PDF/WSSD\%20EU\%20papers.pdf [06/10/2006].

Vogler, John (1999), "The European Union as an Actor in International Environmental Politics”, Environmental Politics, 8 (3), Autumn, pp.24-48.

Vogler, John (2003), "The external environmental policy of the European Union", in: Olav Schram Stokke and Øystein B. Thommessen (eds.), Yearbook of International Cooperation on Environment and Development 2003/4, London: Fridtjof Nansen Institute/Earthscan, pp. 65-71. 
Vogler, John (2005) "The European contribution to global environmental governance" International Affairs, 81 (4), July, pp. 835-849.

Von Frantzius, Ina (2004), "World Summit on Sustainable Development Johannesburg 2002: A Critical Analysis and Assessment of the Outcomes", Environmental Politics, Vol. 13, No. 2, pp. 467-473.

Wagner, Lynn M. (1999), "Negotiations in the UN Commission on Sustainable Development: Coalitions, Processes and Outcomes", International Negotiation, Vol. 4, pp. 107-131.

Wagner, Lynn M. (2005), "A commission will lead them? The UN commission on sustainable development and UNCED follow-up", in: Angela C. Kallhauge, Gunnar Sjöstedt and Elisabeth Corell (eds.), Global Challenges: Furthering the Multilateral Process for Sustainable Development, Sheffield: Greenleaf, pp. 103-122.

Wallström, Margot (2002a), "A Wake-Up Call for Global Sustainability", Speech at the European Policy Centre Dialogue: Sustainability and Globalisation - Towards Johannesburg, 26 February, URL= http://www.europaworld.org/issue71/awakeupcall1302.htm [08/10/06].

Wallström, Margot (2002b), "Conclusions of World Summit on sustainable development in Johannesburg", Environment Commissioner, European Parliament, Strasbourg 25 September,

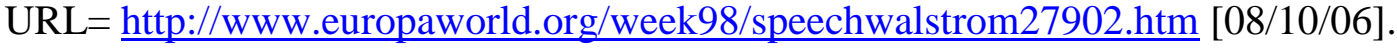

Wallström (2003), "Implementing the WSSD Outcomes", Environment Commissioner, European Parliament, Sustainable Development Inter-Group, 24 September, Strasbourg,

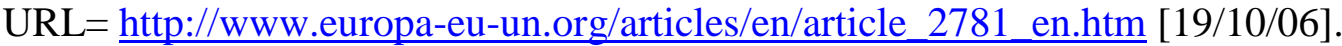

Zito, Anthony R. (2005), "The European Union as an Environmental Leader in a Global Environment", Globalizations, Vol. 2, No. 3, pp. 363-375. 